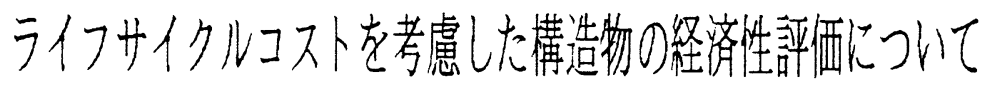

On the Economic Estimation of Life Cycle Cost of Structures

\author{
信州大学大学院 O高沢和典* \\ 信州大学工学部 小山 健**
}

by Kazunori Takasawa and Ken Koyama

\begin{abstract}
土木構造物の耐用年数に対する考え方は，今後の我が国における社会資本の投資の 方法と総量に関係し，かなり重要なものになると考えられる．現在ある構造物につい ては，維持・補修計画に基づき，構造物の寿命を幾分なりとも伸ばすような，いわば 構造物の延命政策が，経済性から見て有利になるかどうかについては，その構造物の 劣化程度, 補修に要する費用, あるいは補修の発生回数および, 耐用年数間にわたり 予想される金利の関係から，大まかに推定することは可能であろう。しかしながら， これから建設する場合の構造物についてはその耐用年数をどのように決定すべきかま た，その場合のライフサイクル費用としてどの程度に設定すべきかについては，構造 物の安全性とも関係する. 本研究は, 総費用最小化原則に基づいた, 構造物のライフ サイクル費用の設定の最適化を目指している，なお，構造物の劣化に関しては，フラ クタル理論を援用し，劣化のパターンを想定することにした．

【キーワード】ライフサイクルコスト, 総費用最小化原則, フラクタル
\end{abstract}

1.まえがき

現在における構造物の耐用年数についての一般的 な考え方としては，1) 経済的耐用年数，2)機能的耐 用年数，3)物理的酎用年数，の 3 通りがあると考え られている. ${ }^{12-3)}$ 現在我が国では, 補修が必要とな る構造物について国および多くの自治体で点検作業 が進められている状況である.

耐用年数は設定されても，多くの構造物がその全 期間供用を全うできるとは限らない。

主に社会的な変遷により，構造物の初期に設定さ れた機能が十分果たせなくなり, 廃棄され更新され る構造物の方が多いとされている. その場合には, ある一定期間は構造物の利用ができなくなる事態も 考虑に入れる必要がある. もちろん予期しない荷重 の発生, 例えば再現期待期間 4)を越えた超過確率を

*信州大学大学院・博前 Tel 026(226) 4101

**社会開発工学科 Tel 026(226)4101 ext.2911
有する地震荷重のようなものが生起した場合には,

構造物は破壊し, この場合にもその構造物は廃棄さ れ更新される.

本研究は，このような事態を考慮にいれた，構造 物の総費用最小化原則に基づいて，ライフサイクル における経済性の評価を試みるものである。一方， 一般に構造物は, 経年劣化を生じ, 適切な維持・補 修の策定計画は不可欠である.

したがって，劣化がどのように進行するのかをあ る程度評価する必要があるが，現実にそれを予測・ 評価することは困難となる．ここでは劣化のパター ンを数式モデルを用いて表現し，経済性評価に組み 込んでいくこととした.

\section{2. 総費用最小化原則について}

一般に，総費用最小化原則に基づく期待総損失費 用は以下のように表される。14-6)

$E\left(C_{T}\right)=C_{1}+C_{1} \cdot p_{f}$ 


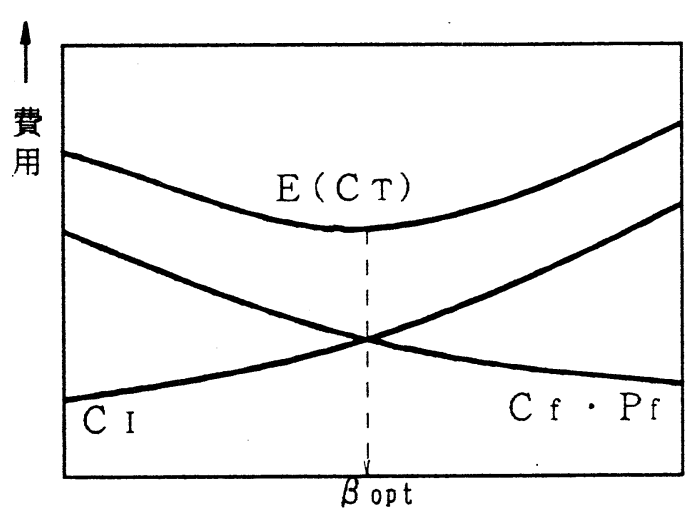

安全性のレベル大きい $\longrightarrow$

困ー1 $\quad C_{\mathrm{I}}$ および $\mathrm{C}_{\mathrm{f}}$ と $\mathrm{E}\left(\mathrm{C}_{\mathrm{T}}\right)$ の概略観念図

ここで, $\mathrm{E}\left(\mathrm{C}_{\mathrm{T}}\right)$ は総損失費用の期待値を， $\mathrm{C}_{\mathrm{I}}$ は構造 物の初期費用を, $\mathrm{p}_{\mathrm{f}}$ は構造物が目的とする機能が果 たせなくなる何等かの限界状態が発生する確率を，

$\mathrm{C}_{\mathrm{f}}$ はその様な事態が発生することによる社会的損失 費用を，それぞれ表すものとする。ただし，ここで は問題を単純化するために，維持・補修あるいは点 検等にかかわる費用については考虑から外してある.

初期費用と社会的損失費用の関係は概略を困一 1

に示す.この図から, 構造物の安全のレベルを上げ ると，構造物にかかる初期費用は増加するが，その 分構造物が何等かの悪い限界状態に陥りにくくなり, その結果としての社会的損失費用は減少することを 表している.したがって，この図から，構造物のラ イフサイクルにおける期待総損失費用はある女全レ ベルにおいて最小となることが期待される. 本研究 ではこの安全レベルでの設計をめざして，耐用年数 をパラメーターにし, 経済性の評価を試みるものと する.

社会的損失費用については次のように仮定した。

建設時で限界が来たとしたときの社会的損失の価 值を $\mathrm{C}$ と仮定したとき, 経過年数 $\mathrm{N}$ 年の時に限界が来 たときの社会的損失の価值 $\mathrm{C}_{\mathrm{f}}(\mathrm{N})$ は利率 $\mathrm{i}$ を考え次の ようになる。

$\mathrm{C}_{\mathrm{f}}(\mathrm{N})=\mathrm{C}_{\mathrm{f}} \cdot \xi^{\mathrm{N}-1}$

ここで， $\xi=1.0+\mathrm{i} ， N は$ 建設時からの経過年数, No は構造物の設計耐用年数である. 社会的損失の価值 が経過年数と共に移りゆく様を図ー2に示した.

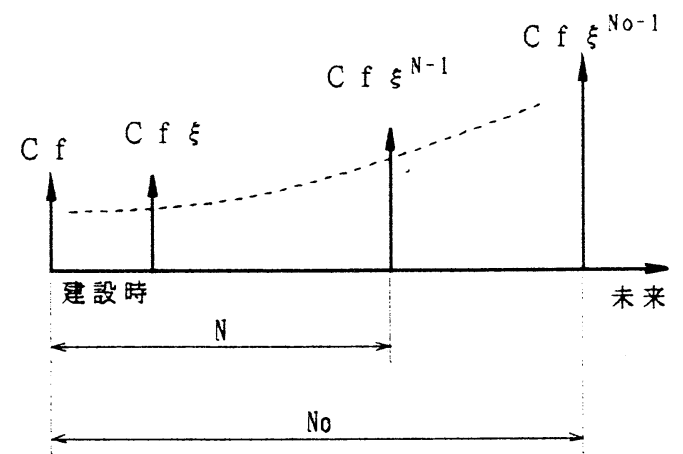

困一２資金流れ図

3. 最適安全性レベルと経年劣化について

(1) 最適安全性指標

信頼性理論に基づく安全性レベルは一般に，2 次 モ一メント安全性指標によって表される，4)，7)，81 安全性指標は, 限界状態を表現する確率変数がどの ような確率分布に従うかによって，また限界状態関 数が確率変数によってどのように書き表されるかに よって，異なった結果が生ずることが指摘されてい る.9).10)

本研究では簡単なために以下に示す安全性指標を 採用する。

$\beta=\frac{\ln \bar{\theta}}{\sqrt{V_{R}^{2}+V_{s}^{2}}}$

ここで, 造物全体の強度 $R$ (二抵抗値) の平均値奋に対する, 想 定荷重Sによって構造物に生ずる断面力(荷重影響)の

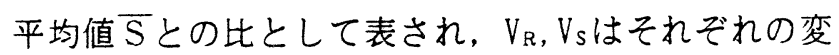
動係数を表すものとする.このとき式(1)の $\mathrm{p}_{\mathrm{f}}$ は一般 に以下のように表される，4）-6)

$\mathrm{p}_{\mathrm{f}}=\Phi(-\beta)$

ここで， $\Phi(\cdot)$ は標準正規分布関数である.

また，構造物の初期建設費用と中央安全率には次 のような関係が仮定できるものとする.

$C_{1}=a(1+b \bar{\theta})$

ここで，a,bは定数である. 式(4)より及が大きく なるほど, 構造物がなんらかの限界状態に達し, 本 来有する機能が果たせなくなる確率が低くなる，す なわち安全性レベルが高くなることを表している。 

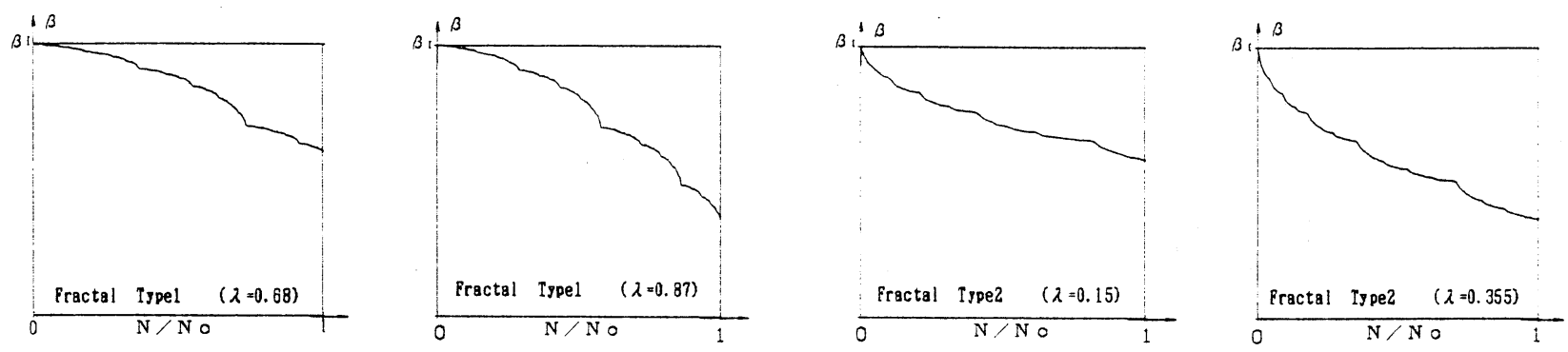

目-3 安全指標の経年変化 $(\alpha=0.3)$

しかしながら全体の経済性からみると図ー1の破線 に相当する安全性レベルが望ましいレベルといえる. このレベルは原理的には, 以下のような式を満足す る $\beta$ を求めることになる.

$\frac{\otimes E\left(C_{T}\right)}{\Delta \beta}=\frac{\nabla C_{1}}{\nabla \beta}+C_{f} \frac{\Delta p_{f}}{\otimes \beta}=0$

式（6）から求められた $\beta$ を最適安全性指標 $\beta$ opt と表すことにする.

（2）経年劣化について

構造物は供用期間に渡って様々な要因から劣化す る.この場合の劣化パターンとしては, 例えば指数 関数を利用したものなどが考えられている。13)-14) しかしながら, 確立されているものはないように考 えられる. 本研究は、この劣化パターンをド・ウィ 一ス(De Hijs)のフラクタルを ${ }^{14)}$ １5) 用いることに よって近似し，そのような劣化パターンを構造物が 有する場合の, 最適安全性指標を決定し, その場合 の経済性の評価を試みることにする.

いま,ド・ウィースのフラクタルをc(s)とした場 合のそれの積分値は以下のように表され，これを劣 化パターンとする.

$d(x)=\int_{0}^{x} c(s) d s$

このモデルは，岩石中に含まれる鉱物の分布状況 が, 鉱物の総量Mが 2 分されるとき，(1-a)M，aMの鉱 物をそれぞれが含有し，この操作を無限に繰り返す 極限として定義されるものである.

ド・ウィースのフラクタルの積分値を用いて次の ような2つの関数を仮定する
$F_{1}(X)=1.0-d(X)$

$F_{2}(X)=d(1.0-X)$

式(8)，(9)から得られる関数值は, 鉱物の含有比率 の意味を含めて, 直接劣化パターンを表現する物理 的な意味は見出せないが，文献14）にもあるように， この関数は連続でほとんどで微分可能でその值は 0 となるが任意の区間でみると単調减少している，横 軸を時間とした時, 日単位での安全レベルの減少は ない（微分=0）が長い日数をみたとき構造物は劣化 しているということより経年劣化(0から $\mathrm{x}$ 年)の説明 として感覚的に合うという理由で採用した。.式(8), （9）を用いた2通りの劣化パターンは比較的劣化の進 む時期と, 比較的劣化の進まない時期が交互に繰り 返されるようになっている.ここでは以下のような 式(10)で表される劣化をType1とし,式(11)で表され る劣化をType2として用いた。

$\beta=\beta_{t} \cdot F_{1}\left(\lambda \cdot \frac{N}{N_{0}}\right)$
$\beta=\beta_{t} \cdot F_{2}\left(\lambda \cdot \frac{N}{N_{0}}\right)$

ここで， $\beta_{1}$ は建設時の安全レベルを，入は劣化の度 合いを表すパラメーターを，№は設計耐用年数を， Nは経過年数を，それぞれ表す。なお式中の係数入に ついては建設時より設計耐用年数 No年が経過したと きの安全レべルがそれぞれ等しくなるようにType1と Type2で次のように設定した.

a)劣化の比較的少ない場合として

Type1では $\lambda=0.68$, Type2では $\lambda=0.15$

b) 劣化が比較的進む場合として

Type1では $\lambda=0.87$, Type2では $\lambda=0.355$ とした. 


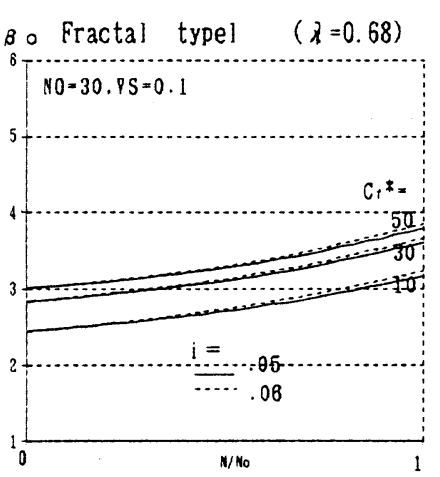

(a)

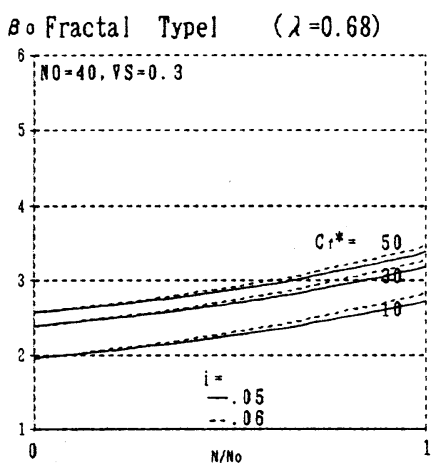

(d)

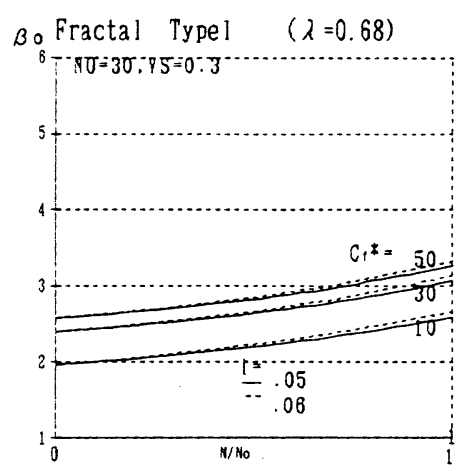

(b)

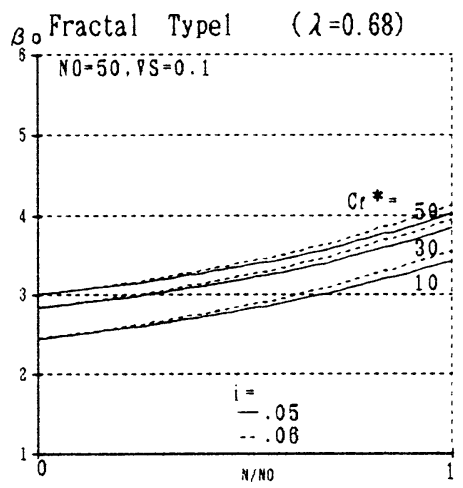

(e)

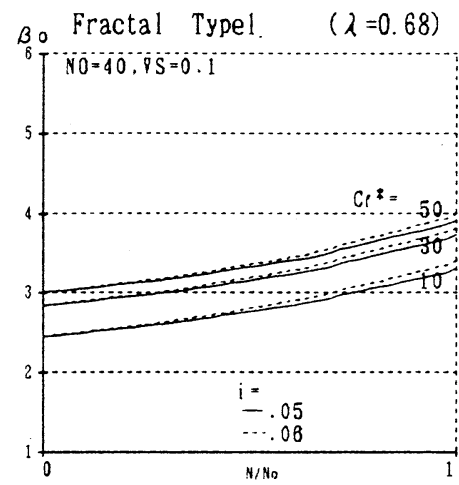

(c)

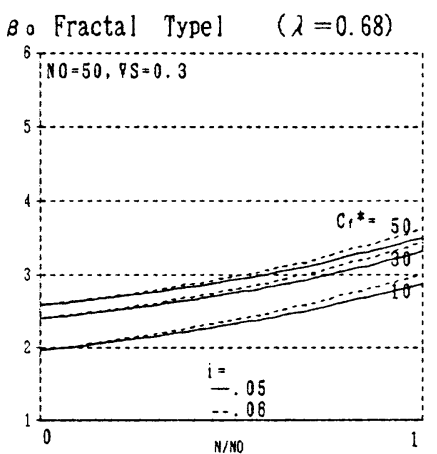

( f )

図-4 最適安全指標と経年変化

いま例として $a=0.3$ の場合の式 (6)から得られたフ ラクタルを図ー3に載せる。 図は横軸に N/No，縦軸 は，安全レベルの劣化を表す安全性指標をとってい る. 何らかの限界状態が生じるまでの経過年数Nは確 率変数であるから特定できないので，式(1)に用いる， $\mathrm{p}_{\mathrm{f}}, C_{\mathrm{f}}$ についてはN年の期間の期待値を用いることに し，以下のように表される.

$$
\begin{aligned}
& \widetilde{\mathrm{P}_{\mathbf{f}}}=\boldsymbol{\Phi ( \widetilde { - \boldsymbol { \beta } } )} \\
& \widetilde{\boldsymbol{\beta}}=\frac{1}{\lambda \cdot N} \int_{0}^{\lambda \cdot N} \beta_{t} F\left(\frac{t}{N_{0}}\right) d t \\
& \widetilde{C_{f}}=C_{f}\left(1+\xi+\xi^{2}+\cdots \cdots \xi^{N-2}+\xi^{N-1}\right) / N \\
&=C_{t}\left(\xi^{N}-1\right) / N(\xi-1) \\
& \text { 以上から式（1）は次の様になる. }
\end{aligned}
$$$$
E\left(C_{T}\right)=a(1+b \bar{\theta})+\widetilde{P_{f}} C_{f}\left(\xi^{N}-1\right) / N(\xi-1)
$$

\section{4. 計算の条件}

本研究では, 式(6)から求められる $\beta ! に$ 対する最 的安全性レベルである $\beta$ optについて次に述べるそれ ぞれの項目をパラメーターとして計算を行い，その 違いにより結果にどのような影響を及ぼすのかを， 定性的に調べていくことにする.

a) 利率について

現在のような低金利は標準的とは考えられないが, 利率 $\mathrm{i}=0.05,0.06$ の 2 通りを仮定し，大幅な金利の上 昇は将来にないものとして考えた。

b) 耐用年数について

大蔵省令による法定的耐用年数は，一般に $40 \sim 50$ 年と考えらているので本研究ではそれを参考にして 30, 40, 50 年の 3 通りで考えた.

c) 構造物全体の強度に対する変動係数について 標準的なものとしてV

d) 想定荷重に対する変動係数について 


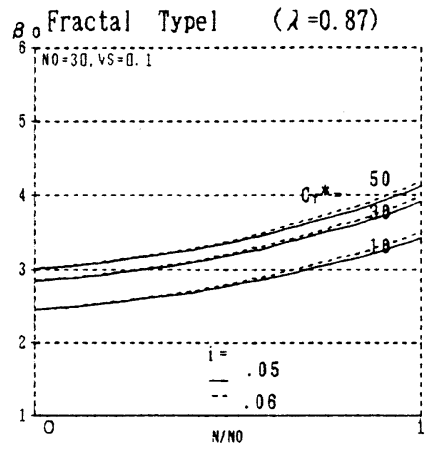

(a)

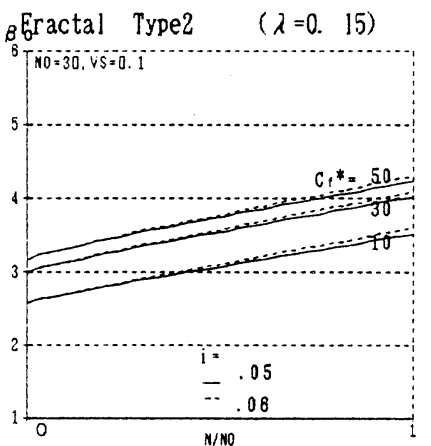

( a )

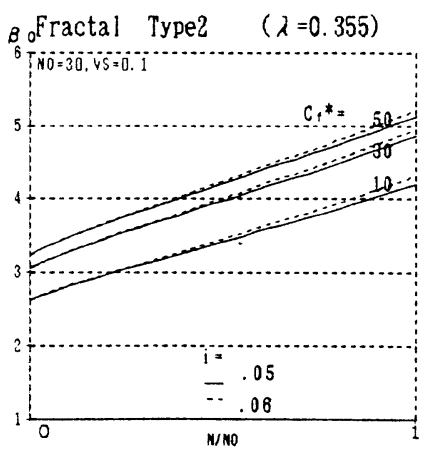

( a )

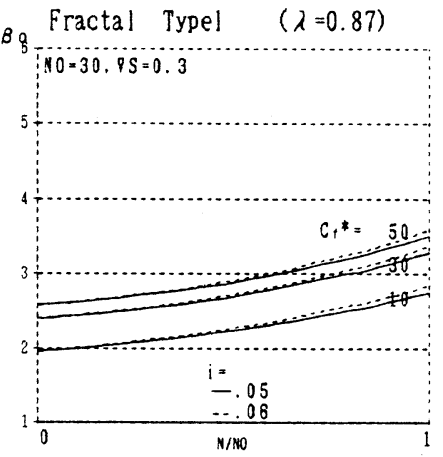

(b)

図一 5 最適安全指標と経年変化

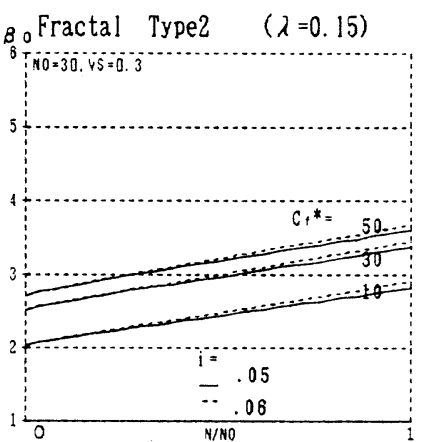

(b)

図一 6 最適安全指標と経年変化

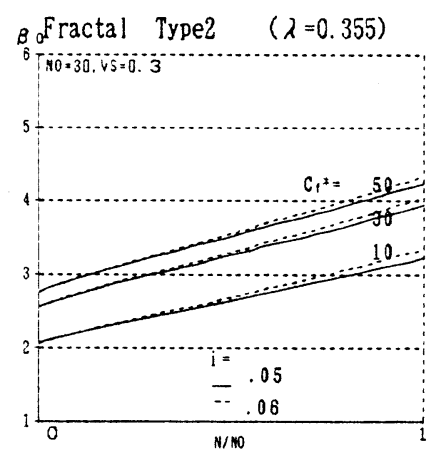

(b)

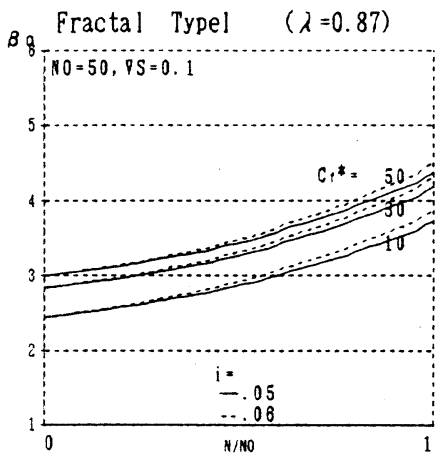

(c)

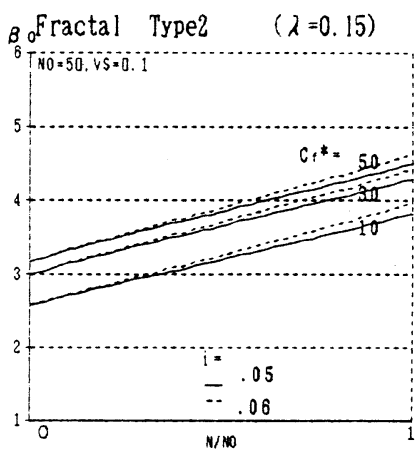

(c)

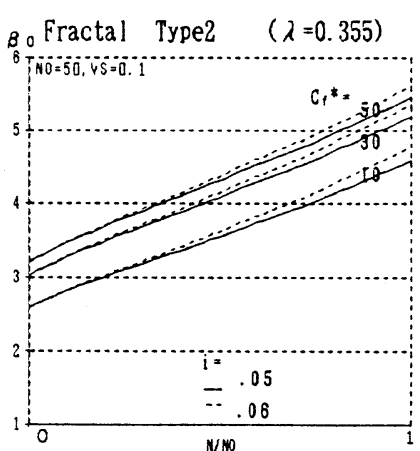

(c)

図-7 最適安全指標と経年変化

荷重についてにのばらつきを想定するのは困難で あるが, 比較的小さいものと, 大きな地震荷重のよ うなものの生起も含めた比較的大きなものを考え， $V_{S}=0.1,0.3$ と仮定した.

e) 社会的損失の費用について
これについても正確に予測するのは困難なので $\mathrm{C}_{\mathrm{f}}{ }^{*}=\mathrm{C}_{\mathrm{f}} /(\mathrm{a} \cdot \mathrm{b})$ と無次元化して, $\mathrm{C}_{\mathrm{f}}{ }^{*}=10,30,50$ と 仮定した。 ${ }^{6)}$ 


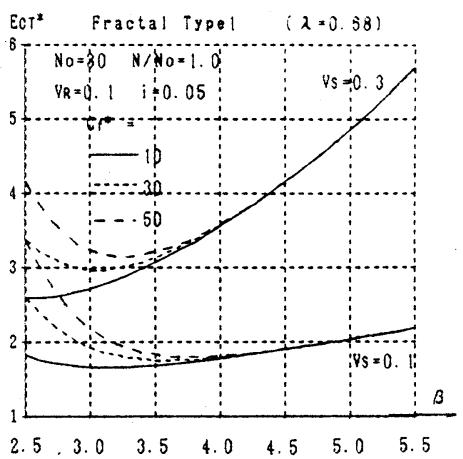

(a)

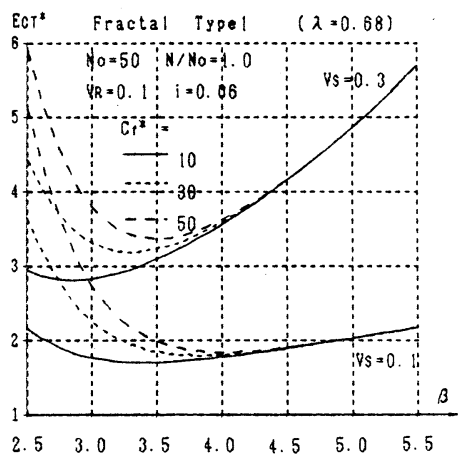

(d)

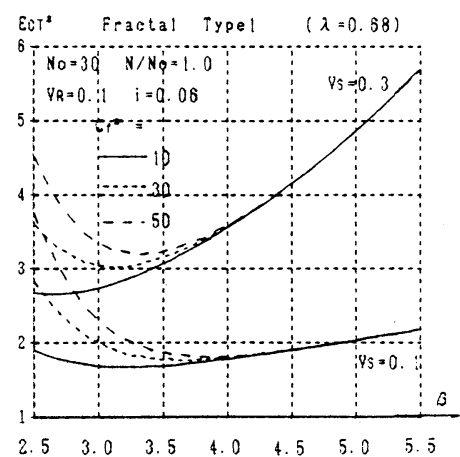

(b)

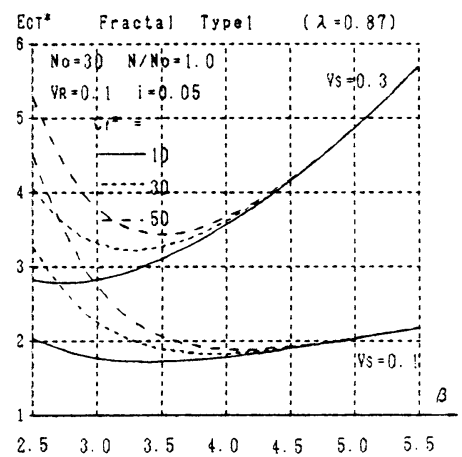

(a)

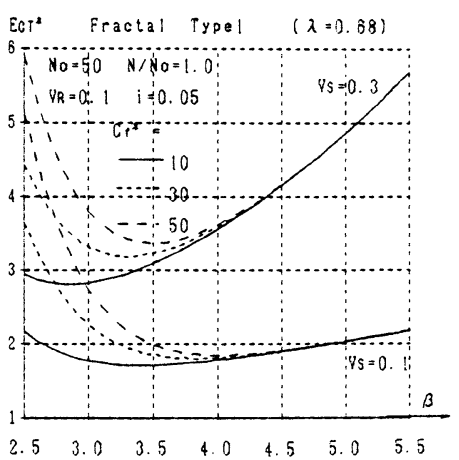

(c)

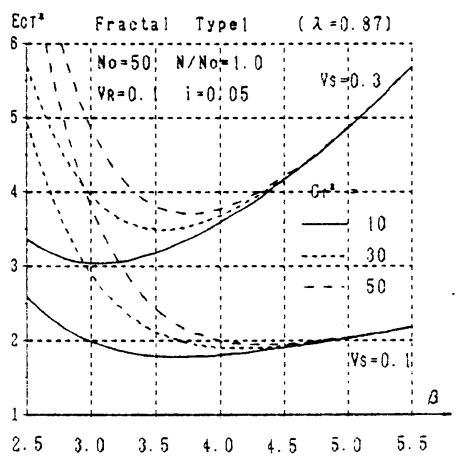

(b)
困-8 安全レベルと期待総損失費用の関係

\section{5．計算結果および結論}

\section{(1) 最適安全指標の経年変化}

式(6)より前節の諸条件の下で $\beta$ に対する最適安全 性レベル $\beta$ optを求めた. Type1で入=0.68の場合を

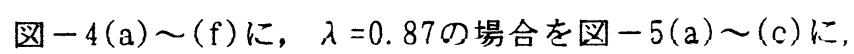
Type2で入 $=0.15$ の場合を図一6(a)〜 (c)に, $\lambda=0.355$ の場合を図ー7(a)〜 (c)に示した. 図中では横軸に, N/Noを，縦軸に最適安全性指標 $\beta$ optをとり，実線と 点線で利率 $\mathrm{i}=0.05, \quad \mathrm{i}=0.06$ の場合とを区別している. これらの図から， (1)図-4(a)〜 (f)よりVsが同じ場合には設計耐用年数 Noに対して限界状態のくる年数Nが長くなるほど，ま た，Noそのものが長くなるほど $\beta$ optは大きく設定す ることが経済性につながることを示している。一方， Vsが大きい場合には, 相対的に安全性のレベルを下 げておいた方が経済性につながり，これらの傾向は， Type1, Type2全体についていえる。なお，
ずかに波打った状態となり，フラクタル劣化の影響 がみられる。

(2)社会的損失費用に関する $C_{f}{ }^{*}$ が大きくなるほど B optを大きく設定することが経済性につながる.

(3)予想される利率が大きくなるほど $\beta$ optを大きく設 定することが経済性につながる。こでは2通りの利 率 $(\mathrm{i}=0.05,0.06)$ について示したが，利率がこれより 上昇すると $\beta$ optはさらに大きくなることが得られる. (4)図-4と図-5, 図-6と図-7の比較より, 劣化の比較 的少ない夕イプに比べ劣化の比較的多いタイプでの $\beta$ optは大きくなっており，比較的大きな劣化の見込 まれる時には, 安全レベルを大きく設定した方が経 済性につながる。

(5) 建設後すぐに劣化の始まるType2のような相対的に 大きな劣化の見込まれるような場合では, 安全レべ ルを相対的にType1のパターンのものより大きく設定 した方が経済性につながる。 


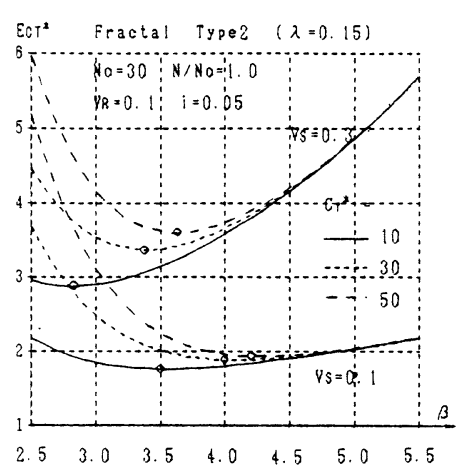

(a)

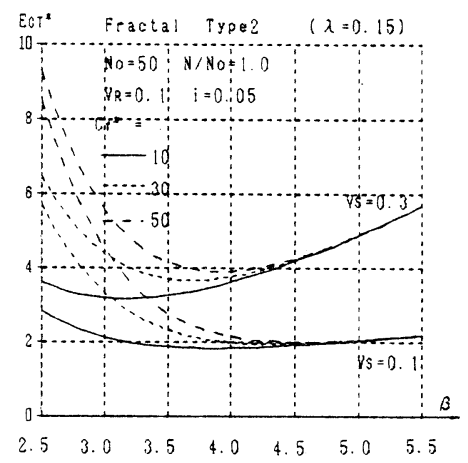

(b)

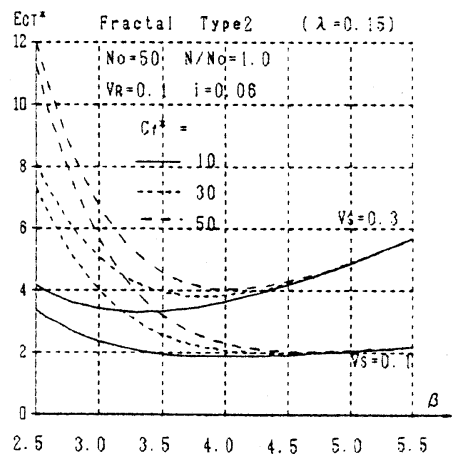

( C )

図-10 安全レベルと期待総損失費用の関係

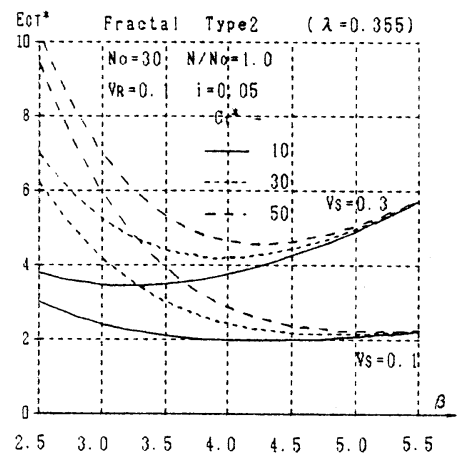

(a)

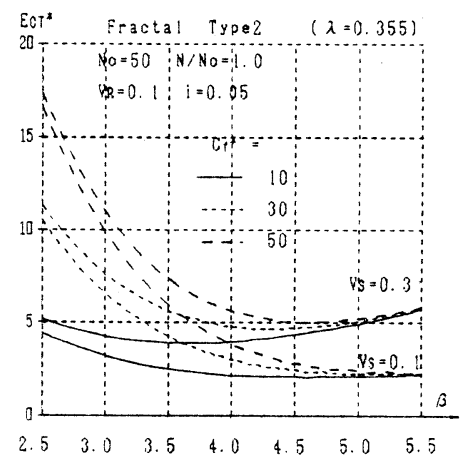

(b)

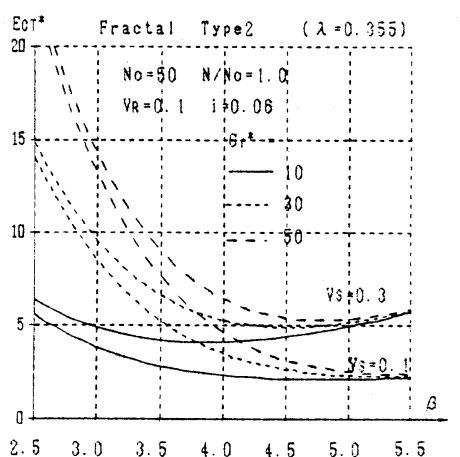

(c)

図-11 安全レベルと期待総損失費用の関係

（2）安全レベルと期待総損失費用の関係

得られた $\beta$ optを用いて式(14)より求められた期待 総損失費用 $\left(\mathrm{E}\left(\mathrm{C}_{\mathrm{T}}\right)\right)$ の最小值と, その周辺から求め られる値の代表的な結果を, Type1で $\lambda=0.68$ の場合 を図-8(a)〜 (d)に, $\lambda=0.87$ の場合を図 $-9(\mathrm{a}) \sim(\mathrm{b})$ に, Type2での $\lambda=0.15$ の場合を図-10(a)〜 (c)に, $\lambda=0.355$ の場合を図-11(a)〜 (c)にそれぞれ載せた. 横軸に建設時の安全レベル $\beta$ をとり縦軸に $\mathrm{E}\left(\mathrm{C}_{\mathrm{T}}\right)^{*}$ を

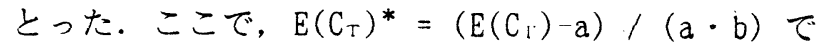
無次元化してある.実線，点線，破線によって， $C_{\mathrm{f}}{ }^{*}=10,30,5003$ 通りを区別した。

また, 荷重の変動係数については $V_{s}=0.1,0.3$ の通り で計算して1つの困中に示した。

(1)図-8 (a)〜 (d)より, 想定荷重に対する変動係数を 大きく設定するほど期待総費用の最小値 $\mathrm{E}\left(\mathrm{C}_{\mathrm{T}}\right)^{*}$ は大 きくなり, Vs=0.3の場合はVs=0.1の場合に比べ1.5倍 程度に上る. これらの傾向は他のパラメーターの組
み合わせでも同様であった。 $\mathrm{E}\left(\mathrm{C}_{\mathrm{T}}\right)$ *最小となる最適 安全性のレベルは3.0から3.5程度と考えてよい。 (2)図-8, 図-9より，条件が同じであれば，フラク夕 ル劣化Type 1 における早期劣化タイプとそうでない タイプの違いは．費用最小にあまり影響がないと思 われる.

(3)図-10,11より, フラクタル劣化Type2では, 安全性 をType1より相対的に上げておく(3.5〜4.0)必要があ る.

(4)図-8と図-10, 図-9と図-110比較より, 全体的に Type1に較べType2の方が期待総費用は大きくなって いる. 建設後すぐに劣化の始まるType2に較べ, 建設 後しばらく後に劣化の始まるType1のような劣化パ夕 ーンの方が経済性に優れている。したがって，でき ることなら劣化パターンが, Typelとなるような維持 ・補修方策を講じることが望ましい。 


\section{6.あとがき}

本研究は構造物のライフサイクル費用の期待総費 用最小化原則に基づいた建設時の最適安全レベルの 設定を目指した。設計耐用年数, 利率, 劣化パター ンおよび想定荷重影響の変動係数の予測の違いが建 設時の最適安全レベルの設定に大きく影響を与えて いることを示した。

しかし, 利率, 変動係数の予測は難しく，また本 研究で採用されたフラクタルによる構造物の劣化夕 イプも物理的意味はそしいことで利用性には問題点 も残るが，一方で，日単位での構造物の劣化はない が長い単位で見ると確実に劣化が進んでいるといっ た感覚的に合う劣化状況を表していると思われるこ とから, 今後のこの方面でのフラクタル劣化パター ンのさらなる研究が待たれる.

\section{【参考文献】}

1)野沢太三：メインテナスの経済的側面，土木学会 誌, pp.17-21,10月号. 1979

2)菅原 操：メインテナンスー今後への展望, 土木 学会誌, pp. 57-62, 10月号, 1979.

3)小堀為雄: 土木構造物の耐用年数一劣化現象とし ての考え方一土木学会誌, pp. 8-12，10月号， 1983.

4) 藤野陽三：確率論に基づく安全性照査法と構造設 計, pp.33-39, 2月号, 1978.

5)杉山俊幸, 酒井利夫, 藤野陽三, 伊藤 学: 構造 設計における信頼性レベル・安全率の設定に関する 考察，土木学会論文報告集，pp. 21-28, No. 327, 1982.
6)小山 健, 土屋宏信, 矢野 勲: 耐用年数を考慮 したコンクリート床版の信頼性に基づいた最適かぶ り厚さ, pp. 221-228, JCOSSAR 91, A-28, 1991.

7) Cornel1, C. A:Structural Safety Specifications Based on Second Moment Reliability Analysis, IABSE Symp. on Concepts of Safety and Methods of Design,

Final Report, 1969.

8) Hasofer, A. M. and Lind, N. C:Exact and Invariant Second Moment Code Format, ASCE, Vol. 100, EM1, 1974.

9) Veneziano, D:Contributions to Second Moment Reliability Theory, MIT Research Report R74-33, 1974.

10) Rackwitz, R:First Order Reliability Methods, Technical Univ. of Munich,

Sonderforshungs-bereich 96, M.chen, 1980.

11)Lind, N. C. :Approximate Analys is and Economic Structures, ASCE, Vol.102,

No. ST6, pp. 1177-1195, 1976.

12)高沢和典, 多田栄一, 小山 健 : 維持・補修を考 慮に入れた橋梁のライフサイクルコストの評価につ いて, 土木学会, 建設マネジメント研究論文集,

Vol.3, pp. 195-206, 1995.

13) 室津義定, 大場史憲, 米沢政昭, 藤井 進: シス テム工学, 森北出版, 1981.2.

14)高安秀樹：フラクタル, 朝倉書店, 1987. 12.

15)ベンワー・マンデルブロ:フラクタル幾何学, 日経サイエ ンス, 1989. 2.

On the Economic Estimation of Life Cycle Cost of Structures

Life cycle cost of structure is optimized based on the principles of expected total cost minimum. The optimum second moment safety index is derived from that principle and the expected minimum cost of prospective structure is estimated by proposed method. Structures are going to deteriorate during the service term. The type of deterioration seems generally neither established clearly nor evaluated exactly. In this study, therefore, fractal type deterioration function is applied to obtain the optimum safety index. 